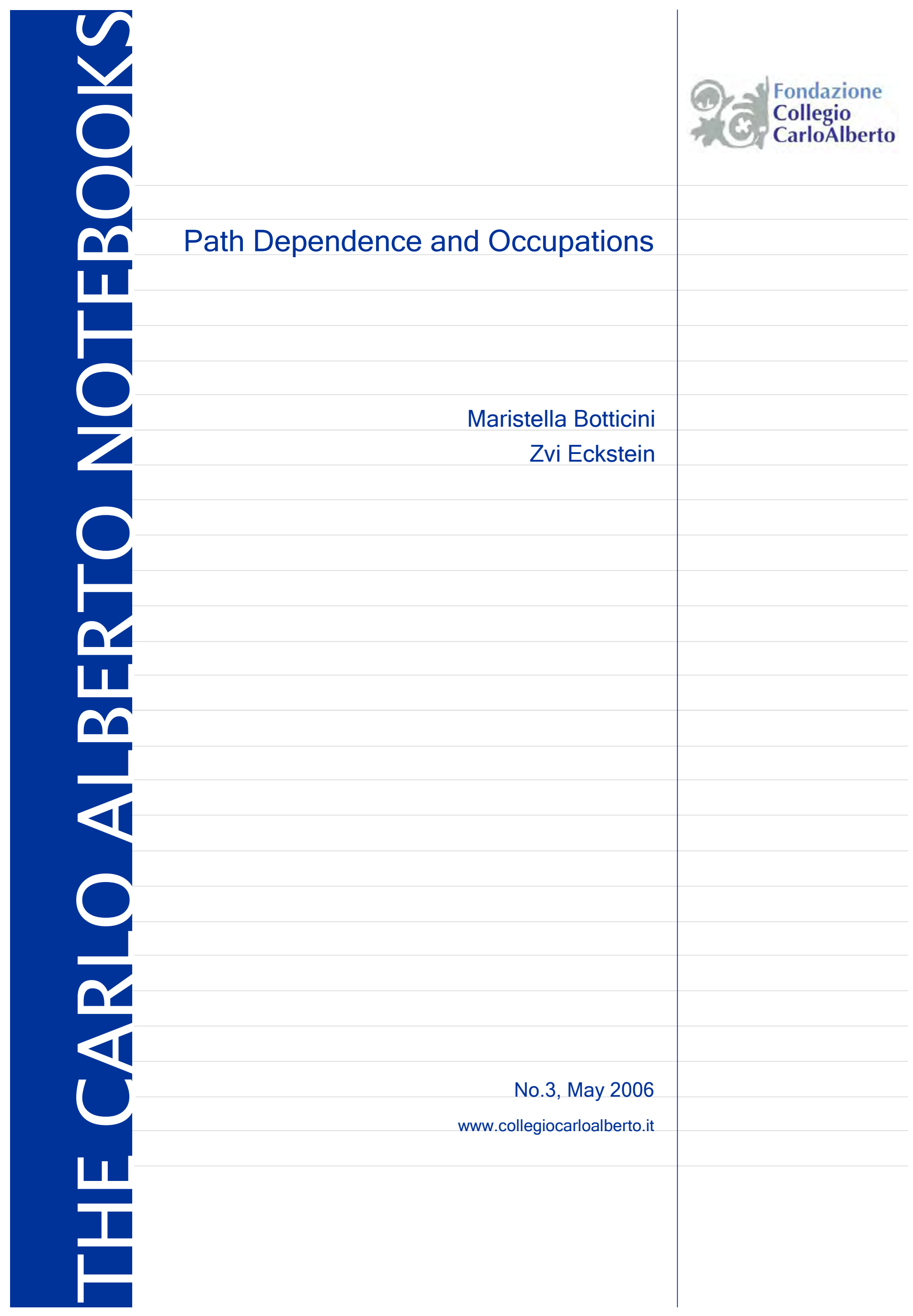




\title{
Path Dependence and Occupations ${ }^{1}$
}

\author{
Maristella Botticini ${ }^{2}$ and Zvi Eckstein ${ }^{3}$
}

Aprile $2006^{4}$

\footnotetext{
${ }^{1}$ A shorter version of this paper is forthcoming in Lawrence Blume and Steven N. Durlauf (eds.), The New Palgrave Dictionary of Economics, 2nd edition. We are indebted to Robert Margo, Joel Mokyr, Andrew Newman, and the Palgrave editors Larry Blume and Steven Durlauf for very helpful suggestions. Botticini thanks the Fondazione Collegio Carlo Alberto for financial support and the Federal Reserve Bank of Minneapolis for its hospitality.

${ }^{2}$ Fondazione Collegio Carlo Alberto, Università di Torino, Boston University, CHILD, and CEPR.

${ }^{3}$ Tel Aviv University, University of Minnesota, Federal Reserve Bank of Minneapolis, and CEPR.

${ }^{4}$ (C) 2006 by Maristella Botticini and Zvi Eckstein. Any opinions expressed here are those of the authors and not those of the Fondazione Collegio Carlo Alberto.
} 


\begin{abstract}
Path dependence in occupations refers to the observed occupational distribution in a population or in a sub-population at a point in time that depends on changes that occurred years or centuries earlier. Path dependence in occupations can be the outcome of the cumulative concentration of certain productive activities in specific regions over time, it can emerge through the effect of parental income or wealth on offspring's occupations and incomes, or it can be the outcome of group effects. Some historical cases are selected to illustrate the various mechanisms through which path dependence in occupations can emerge or disappear.
\end{abstract}

JEL Classification: J1, J2, J6, J7, N3, O1, Z12, Z13

Keywords: path dependence, occupational structure, social norms, trade diasporas, Jewish occupational selection, feminization of occupations, AfricanAmerican occupational transition 


\section{Introduction}

Path dependence in occupations can be interpreted to mean that the observed occupational distribution in a population or in a sub-population at a point in time depends on changes that occurred years or centuries earlier (for example, a war that siphons off certain types of workers, the enactment of anti-discriminatory labour practices, a technological invention which is not gender- or race-neutral). This definition is consistent with the notion of path dependence suggested in the economic history literature by David (1985) with the example of the 'standard QWERTY' keyboard. Under this definition one can include both the cases in which particular innovations in the economy have permanent consequences and those instances in which particular shocks are not self-correcting, so that they remain permanent in the absence of some countervailing change.

To show that there is path dependence in occupations, one has to describe the exact sequencing of events related to the initial change and show that they had a permanent effect on the occupational choice and distribution observed later. In other words, one has to show that, at a given point in time, multiple occupational distributions were available for selection, and theory is unable to predict or explain the occupational structure that will be chosen. Then, a change occurs and an occupational distribution is favoured over competing ones. Finally, the selected occupational structure capitalizes on initial advantage and is stably reproduced over time.

The economics literature identifies a number of possible sources of path dependence (see for discussions Arthur, 1989; David, 1994; Liebowitz and Margolis, 1995; Blume and Durlauf, 2005). For example, the economic geography literature explains path dependence in occupations as the outcome of the cumulative concentration of certain productive activities in specific regions over time (for example, Krugman, 1991b; Fujita, Krugman and Venables, 1999). This literature highlights the potentially big impact of increasing returns and cumulative processes, which in turn can make the role of historical accidents decisive. Small changes in the parameters of the economy may have large effects. For example, if transportation costs, economies of scale, and the share of non-agricultural goods in expenditure cross a critical threshold, population may start to concentrate and regions to diverge; once started this process will feed on itself.

However, increasing returns are not necessary for path dependent processes (Bowles and Gintis, 2002). For example, in models of intergenerational mobility where individual-level characteristics matter (for example, Becker and Tomes, 1979; Loury, 1981; Banerjee and Newman, 1991; 1993; Galor and Zeira, 1993; Eckstein and Zilcha, 1994; Mookherjee and Ray, 2002; 2003), the existence or absence of path dependence in relative economic status across generations emerges through the effect of parental income or wealth on offspring's occupations and incomes. 
In contrast, starting from the seminal work of Shelling (1971), in membership models an individual's economic choices are influenced not only by his or her traits but also by characteristics of the group of individuals with whom the person typically interacts (see Durlauf, 2006, for a discussion of these models and related empirical literature). Groups may differ in average level of schooling, cognitive functioning, occupational structure and wealth level. Some groups are exogenously determined, for example by ethnicity or gender. Other groups are endogenously determined. For example, individuals may be strongly influenced by groups such as residential neighbourhood, the schools attended, and the co-workers at various jobs. Group effects on economic success are well documented and may arise for a number of reasons, including discrimination, conformist effects on behaviour, differential access to information, and complementarities in production.

An exhaustive survey of historical and contemporary examples of path dependence in occupations is beyond the scope of this article. Instead, we selected some examples which illustrate the various mechanisms discussed above through which path dependence in occupations can emerge or disappear.

\section{Jewish Economic History}

At the beginning of the first millennium, an exogenous change in the religious and social norm that defined Judaism occurred as a result of the shift in the leadership within the Jewish community. Before the destruction of the Temple in Jerusalem in $70 \mathrm{CE}$, the Jewish population in Eretz Israel, which consisted mainly of farmers, was segmented in many religious groups. After the destruction of the Temple, many Jewish sects disappeared, whereas the Pharisees became the dominant group. They replaced sacrifices with the study of the Torah in the synagogue. The transformation of the religion created the need for the devoted Jews to be literate and to educate their children. In about $200 \mathrm{CE}$, the transformation of Judaism reached its full-fledged stage with the compilation of the Mishna. Also, a new social norm came to prevail according to which an illiterate Jewish individual was considered an outcast in the community.

Despite education being very costly and 'useless' in production for farmers, religious instruction and primary education became more and more widespread among the Jewish communities in Palestine and Babylonia from the second to the seventh century. The spread of literacy among the Jewish rural population is even more impressive when compared with the literacy rates of the non-Jewish rural population in the same period. In the Roman, Byzantine, Christian and Persian worlds there was no mandatory primary education, and the non-Jewish rural population was almost entirely illiterate. 
Before $400 \mathrm{CE}$ almost all Jews in the three main centres of Jewish life in the classical period - Palestine, Babylonia, and Egypt - were farmers, exactly like the rest of the population. The transition away from agriculture into crafts and trade started in the Talmudic period (200-500 CE), especially in Babylon. In the fifth and sixth centuries, some literate Jews abandoning agriculture moved to the towns and became small shopkeepers, craftsmen and artisans. However, given the stagnant economies in the late Roman, early Byzantine and Persian empires in the fourth to the seventh centuries, the growing number of literate Jewish farmers could not find skilled occupations in the existing cities at that time and many of them converted out of Judaism. World Jewry was reduced from about 4.5 million in $70 \mathrm{CE}$ to about 1.5 million in $600 \mathrm{CE}$, with 80 per cent living in Babylonia.

But in the eighth and ninth centuries, another exogenous event occurred: massive urbanization in the newly established Muslim empire under the Abbasid caliphate vastly increased the demand for urban, skilled occupations. The literate Jewish rural population in Iraq and later in the Abbasid empire as a whole moved to urban centres, abandoned agriculture, and became engaged in a wide range of crafts, local and long-distance trade, moneylending, tax-farming and the medical profession. This occupational transition took about 150 years, and by 900 almost all Jews in Iraq, Persia, Syria and Egypt, were engaged in urban occupations. In contrast, most non-Jews remained farmers, even though they could engage in any occupation in the regions under Muslim rule. These two facts identify the educational reform in Judaism around $200 \mathrm{CE}$ as the key factor for the occupational transition of the Jewish people (Botticini and Eckstein, 2005).

Judaism, with its costly religious norm regarding education, can thrive in the long run only if the Jews can find occupations in which their earnings significantly gain from literacy (Botticini and Eckstein, 2006). The voluntary diaspora of the Jews to western Europe during the tenth to the 13th centuries, to eastern Europe in the 16th and 17th centuries, and then worldwide supports this argument. Other minorities within the Muslim empire under the Abbasid caliphate did not migrate to western Europe even though no prohibitions prevented them from doing so. The distinctive engine of the Jewish migrations to the West was the incentive to maximize the returns to their investment in education. Hence, these two facts identify the link between the 'historical accident' and the voluntary diaspora of the Jews in search of urban, high-skill and high-income occupations.

The large Jewish population of Iraq and Iran, which amounted to about 800,000 in 1250, almost disappeared when the Mongol invasions brought the Near East back to a subsistence farming economy. In contrast, the small Jewish population in Europe survived, kept its literacy and educational distinctiveness, and through urban and skilled occupations reached high standards of living.

These urban, skilled occupations remained the distinctive mark of the 
Jewish people throughout their history, as clearly highlighted by the data provided by Kuznets (1960): in the countries which hosted the largest Jewish communities in the early 20th century (countries in eastern Europe, Russia, the United States and Canada), between 96 and 99 per cent of the Jews were engaged in non-agricultural occupations even though no restrictions prevented them from being farmers.

Table 1-Occupational Structure of World Jewry, Ca. 1930

\begin{tabular}{lccc}
\hline \hline Country & Year & $\left(\frac{\text { Jews in nonagr. jobs }}{\text { Jewish labor force }}\right)$ & $\left(\frac{\text { Non-Jews in nonagr. jobs }}{\text { Non-Jewish labor force }}\right)$ \\
\hline Poland & 1931 & 96 & 47 \\
Soviet Union & 1926 & 96 & 27 \\
United States & 1940 & 98 & 82 \\
Latvia & 1930 & 99 & 47 \\
Germany & 1933 & 99 & 83 \\
Czecholosvakia & 1930 & 91 & 73 \\
Hungary & 1930 & 97 & 52 \\
Rumania & 1930 & 96 & 37 \\
Bulgaria & 1926 & 99 & 31 \\
Canada & 1931 & 99 & 71 \\
\hline
\end{tabular}

Source: This table reproduces Table 2 in Kuznets (1960, p. 1608).

Chiswick (2005) documents the same occupational selection of the Jewish population in the United States as late as the year 2000. For example, about 53 per cent of adult Jewish men are engaged in professions such as law, medicine, and academia, whereas the percentage for white non-Jewish men is about 20 per cent. In contrast, only six per cent of adult Jewish men are employed in the construction, transportation, and production sectors in comparison with about 39 per cent of adult non-Jewish men.

Jewish economic history fits very well the multiple features of path dependence outlined in the Introduction. On the one hand, two exogenous changes (the transformation of the religious norm in the first and second centuries $\mathrm{CE}$ and the urbanization in the Muslim empire in the eighth and ninth centuries) created a permanent effect on the occupational distribution among the Jews. On the other hand, the mechanisms through which these changes worked to affect the occupational structure of the Jews in the long run were twofold: the intergenerational transmission of skills and literacy from parents to children, and the peer pressure (social penalty) that the Jewish communities imposed on those who did not invest in their children's education. 


\section{Commercial and Trade Diasporas}

As membership models would predict, ethnic groups can influence the occupational distribution of immigrants in a country and create occupational clustering by ethnicity. One of the most visible examples of this occupational clustering is offered by the so-called commercial and trade diasporas.

A diaspora is any ethnic group without a territorial base within a given polity, and whose social, economic and political networks cross the borders of nation states. In particular, trade and commercial diasporas are those diasporas whose members specialize in trade and commercial activities or, more generally, in urban, skilled jobs. Historical examples include the Jews in the last two millennia, the Parsi (Zoroastrian) diaspora from Iran, the Huguenots in early-modern and modern western Europe, the Armenians, the Greeks of the Ottoman Empire, the Germans throughout eastern Europe in modern times, the Chinese in many areas of south-east Asia from the 15th to the 20th century, the Indian middleman minorities of east Africa and Malaya, the Pakistanis in Great Britain, and the Lebanese Christians in 18th-century Egypt and contemporary west Africa (Botticini, 2003).

Commercial and trade diasporas - indeed, diasporas in general - have been characterized by strong linguistic skills, often including the ability to speak and write in both their own and alien languages. This enabled members of a diaspora to maintain communication networks within the group and to use alien languages for practical purposes. Maintaining the common original language is one of the means to enhance the organization of a diaspora. Others mechanisms include the establishment of communal institutions, such as the commercial coalitions among the Jews in the Mediterranean in the high Middle Ages (Greif, 1989) or the Chinese societies known as Houei; the development of a common set of commercial laws or norms whose enforcement is delegated to courts within the communities; and strong endogamous marriage strategies.

In some cases, exogenous changes have created or reinforced occupational selection among ethnic or religious groups. For example, it has been often argued that legal prohibitions and the exclusion of Jews from guild membership in medieval and early-modern Europe would account for their occupational selection into moneylending and the medical profession. Similarly, it has been pointed out that, after the revocation of the Edict of Nantes by King Louis XIV in 1685 that made Protestantism illegal, many Huguenots (French Protestants) emigrated to Ireland, England, Prussia, and America, where they contributed to the development of industries and trades. The Agricultural Law of 1870 in Indonesia against land ownership by ethnic Chinese has been cited to explain the exclusion of the Chinese diaspora from farming and agricultural activities.

In other instances, the occupational distribution was altered by rulers who substituted one diaspora for another if they perceived the change to be 
advantageous for them. Thus, in the Ottoman Empire, Catholic Levantines, who held the leadership in crafts and trade in the 15th century, were replaced by the Jews in the 16th and 17th centuries, followed by the Greeks until the beginning of the 19th century and Armenians during the 19th century.

Geography also played a role in the occupational specialization of some ethnic groups. With the European geographical expansions and the establishment of colonial rule in south-east Asia and west and east Africa during the 19th and 20th centuries, Lebanese Christians, Chinese, and Indians have contributed to the establishment of commercial economies in the European colonial empires.

\section{The Manufacturing Belt in the United States}

The establishment and remarkable persistence of the manufacturing belt in the United States is one of the most prominent examples of geographic concentration which in turn affected the occupational distribution of the US population.

Early in the history of the United States, when most of the population was engaged in agriculture, when transportation costs were high, and when manufacturing was characterized by few economies of scale, no concentration could occur. When the United States started to industrialize, manufacturing first developed in regions where most of the agricultural population outside the South was located. The manufacturing belt developed in the second half of the 19th century when economies of scale in manufacturing increased, transportation costs fell, and the share of the population in non-agricultural occupations rose. The initial advantage of the manufacturing belt was locked in, leading the bulk of US manufacturing to be concentrated in a relatively small part of the north-east and the eastern part of the Midwest. It persisted even as the centre of gravity of agricultural and mineral production shifted to the West. As late as 1957, the manufacturing belt still contained 64 per cent of US manufacturing employment (Krugman, 1991a).

\section{$5 \quad$ Intergenerational Occupational Mobility in Britain and the United States}

Unlike today, the United States in the 19th century was 'exceptional' in the occupational mobility experienced by its population (as well as in its geographic mobility) compared with Europe. As documented by Long and Ferrie (2005), this contrast is even more striking when 19th-century United States is compared with 19th-century Britain - the country with which it shared legal traditions and property rights systems and sources of labour, capital, and technology. 
Differences have been attributed to a number of factors. First, the absence of feudalism and of strong craft guilds has been put forth as one reason for the higher occupational mobility in the United States. Second, at least some of the high mobility in 19th-century United States may result from it being at an earlier stage of development than 19th-century Britain, so its farm sector was relatively larger.

Third, the United States provided considerably more public education than Britain in the middle of the 19th century: the primary school enrolment rate was one and a half times greater in the United States than in Britain. The US educational system in the second half of the 19th century, though less extensive at the secondary and post-secondary levels than European systems, was considerably more egalitarian (Goldin and Katz, 2003). To the extent that intergenerational mobility is greater where fewer parents are wealth-constrained, superior mobility in the United States may well have been a consequence of its educational system, which provided a public alternative to a private education that was outside the reach of many families.

Fourth, residential mobility to places that were growing more rapidly than others may have provided an alternative to direct investment in human capital. Cities (such as Chicago) sprang up initially to provide services demanded as the frontier expanded. Though US labour markets in the North were well-integrated at the regional level by the middle of the 19th century, differences across smaller units of geography may have continued to present opportunities for 'locational arbitrage' that provided a route to occupational change through the start of the 20th century (Long and Ferrie, 2005).

\section{The Feminization of Teaching and Clerical Work}

\section{Teaching Profession}

Today in the United States the vast majority of elementary and secondary teachers are women. In 2000, the female proportion among teachers was 76 per cent. Much earlier in American history, however, this was not the case. The feminization of teaching occurred over the course of the 19th century and continued throughout the 20th century. Two exogenous factors changed the social norm and attitude towards female teachers in the United States and, therefore, significantly contributed to the feminization of teaching: (a) the ethnic, national, and cultural identity of the European settlers who established their communities in the Northern, Midwestern, and Southern states, and (b) the wars (especially the American Civil War and the First World War).

Relatively early in the 19th century, women came to dominate teaching in New England through the establishment of two educational institutions: 
the so-called 'dame schools' and a two-tier system divided into winter and summer sessions. The 'dame schools' were an educational institution imported by British settlers, in which women taught very young children as they were considered the natural carers for these children. The division into winter and summer sessions reinforced this gender-specific assignment of teachers to pupils according to age. As winter sessions were geared towards older boys, male teachers were considered to have greater human capital and skills to enforce discipline among them. Female teachers were considered better equipped to teach summer sessions attended by younger children. As population spread westward in the North, the female percentage in teaching increased in these states (Carter and Margo, 2007).

In contrast, because of the different ethnic and national background of the European settlers who established themselves in the U.S. South, neither 'dame schools' nor the two-tier system were developed and the percent of female teachers remained much lower there until the Civil War. But even within the North itself, the role of culture and institutions in affecting the gender distribution in the teaching profession is illustrated by regional variation. In Illinois counties where the settlers were mainly Yankees, female teachers were quite common, whereas in those counties where the settlers were mainly Southerners, male teachers predominated (Carter and Margo, 2007).

As Perlmann and Margo (2001) have shown, the American Civil War significantly contributed to the feminization of teaching. In 13 Northern and Midwestern states, the average share of female teachers rose from about 57 per cent in 1860 to 67 per cent in 1865 and 79 per cent in 1915. During the war women took jobs in teaching, substituting for men who were at war. When the war ended, there was some mean reversion, but not back to the original equilibrium.

The entry of many women into teaching during the Civil War changed the social norm and attitudes toward female teachers by making the bias against them gradually fade. In the earlier decades, the argument against hiring female teachers had been that, especially in winter classes when adult boys attended school, women lacked the skills to discipline these students. However, the entry of women in the teaching profession during the war to substitute for the male teachers gave them the opportunity to show that they could be as effective as their male colleagues in teaching and maintaining the discipline among students. This changed the social norm and attitude toward hiring female teachers, which increased the feminization of teaching in both the Northern states and in the South, where the share of female teachers reached unprecedented levels, rising from about 35 per cent in 1875 to 73 per cent in 1915 (Perlmann and Margo, 2001, p. 169).

The First War World had a similar effect on the selection of women into the teaching profession, although on a smaller scale. After the Second World War, women entered many other occupations and professions. Yet 
the predominance of female teachers in primary and secondary schools holds to the present day.

Clerical work

In 1870, fewer than three per cent of all clerical employees were women. In 1930 , women made up over half (52.5 per cent) of the total clerical workforce, and today the clerical sector is one of the major employers of women. The most rapid increases occurred in two decades, 1880-90 and 1910-20, as the outcome of two exogenous shocks on the demand side of the labour market coupled with a profound transformation on the supply side of the same market.

On the demand side, Rotella (1981) has argued that the adoption and diffusion of the typewriter in the 1880s, the growth of large firms and the expansion of the government sector in the 1910s created a huge demand for clerical work. Specifically, the diffusion of the typewriter made the skills required of clerical labour no longer firm-specific, as it had been when employers preferred to hire male workers who were expected to have a long working life within the firm. With the development of the modern, mechanized office, employers could afford to hire young, educated women who had high expected turnover and who desired clean, high-status employment. Later, in the 1910s, the growth of large firms and the expansion of the government sector through regulation and tax laws greatly increased the demand for information and information processing within firms and government offices. Again, this shift in demand was not gender neutral: it favoured women, and women came to dominate office work, basically after about 1910 .

On the supply side, Goldin $(1986 ; 1990)$ has shown that the huge increase in high school attendance around the turn of the 20th century - the socalled 'high school movement' - dramatically increased the supply of young, educated women in the labour market. These women offered a relatively cheaper and easier to monitor labour force.

\section{The Occupational Transition of African-Americans}

After the American Civil War, a steady stream of African-Americans moved out of the South to the North. It has been estimated that from 1870 to 1910 about 535,000 blacks emigrated from the South on the net as the outcome of the large wage differentials between the North and the South and of the increased human capital acquired by the first generations of blacks after the Emancipation (Margo, 1990, ch. 7). This migration, though, did not have a huge impact on the overall occupational and residential distribution of African-Americans. In fact, in 1900 approximately 90 per cent of the blacks still lived in the South, and the majority of them worked in agriculture and were very poor. 
In contrast, from 1910 to 1950 the Great Migration brought about 3.5 million African-American people out of the South mainly to the urban North. Even when migration occurred to rural areas in the North, it invariably involved a shift out of agriculture. The Great Migration represented a watershed in African-American economic history and implied a profound and permanent transformation of the occupational distribution of the blacks in the United States.

The relevant exogenous shocks that fuelled both the Great Migration and the permanent change in the occupational distribution of the blacks were the two world wars and a combination of government policies.

First, quotas set by the US government on foreign immigration after the First World War greatly accelerated the outmigration of blacks from the South in the 1920s, as blacks were substitutes for the foreign-born immigrants (Collins, 1997).

Second, the Second World War was an even bigger exogenous shock. When the United States entered the war, demand for white workers in the war-industry sector increased at the same time as the military was siphoning off potential workers. US employers were faced with a tough choice: either to follow the prevailing taste for discrimination among employers and white workers and the social norm against hiring black workers, or to expand production and to gain profits by hiring black workers.

The enforcement by President Roosevelt of the anti-discriminatory policy amongst defence contractors through the Fair Employment Practice Committee (FEPC) established in 1941 was the exogenous change in government policy that helped employers choose the second option and hire black workers despite the prevailing taste for discrimination (Collins, 2001). The impact of this government intervention was twofold. It made defence contractors hire black male workers who otherwise would not have been hired because of the hostility of white male workers towards hiring fellow black workers. At the same time, it started changing the social norm and attitude against hiring black workers in other firms and industries in those instances when the enforcement of the anti-discriminatory policy among the defence contractors sector had spillover effects on other firms' hiring practices.

The combination of the two exogenous shocks - the Second World War and the establishment of the Fair Employment Practice Committee - had a large impact on the occupational and residential transition of AfricanAmericans. Between 1940 and 1950 the proportion of black male workers classified as operatives (semi-skilled) rose from 12.6 to 21.4 per cent, and the proportion in manufacturing industries rose from 16.2 to 23.9 per cent (Collins, 2000). This transition into manufacturing and war-related industries greatly contributed to the economic progress of blacks, as the data on the substantial wage premium these workers earned indicate.

A similar effect occurred ten years later as the outcome of another major change in government policy. The Brown vs Board of Education Supreme 
Court's decision in 1954, which invalidated school segregation in the US South, the enactment of Title VII of the 1964 Civil Rights Act, which forbade discrimination in employment, the establishment of the Office of Federal Contract Compliance (OFCC), which monitored the anti-discrimination and affirmative action responsibilities of government contractors, and the passage of the Voting Rights Act of 1965 were the most famous among several government policies designed to eliminate discrimination against blacks. Donohue and Heckman (1991) show that a significant portion of the sustained improvement in the labour market status of black males from 1965 to 1975 (especially in the US South) was the outcome of these changes in government policies.

\section{Poverty Traps}

Intertemporal social interactions (that is, social interactions in which choices made at one time affect others made later) can create path dependence in occupations through a variety of mechanisms. Role models and peer group effect models are two examples of these mechanisms. Suppose, as role models do, that the decision to attend college by a young adult depends on the percentage of college graduates among adults in his community. Then two communities, one where the adults are all college graduates and the other where none is, can converge to different levels of college attendance in a steady state, leading to path dependence in occupational and economic segregation across long time periods and generations.

The persistence of ghettoes and poverty traps are the two most visible examples of the intertemporal effect of group membership on individual outcomes (Bowles, Durlauf, and Hoff, 2006). Poverty traps are situations where the evolution of individual wealth is governed by a path-dependent process such that, depending on initial conditions, otherwise identical individuals or groups (ethnic, linguistic, religious) may remain for long periods of time 'locked into' poverty. The key characteristic of a poverty trap is that the 'good' and 'bad' outcomes are self-enforcing, so that small interventions or chance events will not alter the long-term outcome. Recent evidence of the persistence of income differences between races, even after some of the structural determinants of inequality (such as colonialism, inequalities of educational opportunity, and de jure segregation) have been removed, point to the importance of historical contingency and 'lock-in effects' in the process that generates inequality (Loury, 2002; Bowles, 2006). 


\section{References}

[1] Arthur, W. "Increasing returns, competing technologies and lock-in by historical small events: the dynamics of allocation under increasing returns to scale." Economic Journal 99 (1989): 116-31.

[2] Banerjee, A. and Newman, A. "Risk-bearing and the theory of income distribution." Review of Economic Studies 58 (1991): 211-35.

[3] Banerjee, A. and Newman, A. "Occupational choice and the process of development." Journal of Political Economy 101 (1993): 274-98.

[4] Becker, G. and Tomes, N. "An equilibrium theory of the distribution of income and intergenerational mobility." Journal of Political Economy 87 (1979): 1153-89.

[5] Blume, L. and Durlauf, S., eds. The Economy as an Evolving Complex System III: Current Perspectives and Future Directions. Oxford and New York: Oxford University Press, 2005.

[6] Botticini, M. "Commercial and trade diasporas." In Oxford Encyclopedia of Economic History. New York: Oxford University Press, 2003.

[7] Botticini, M. and Eckstein, Z. "Jewish occupational selection: education, restrictions, or minorities?" Journal of Economic History 65 (2005): 922-48.

[8] Botticini, M. and Eckstein, Z. "From farmers to merchants, voluntary conversions and diaspora: a human capital interpretation of Jewish history.” Discussion Paper No. 5571. London: CEPR, 2006.

[9] Bowles, S. "Institutional poverty traps." In Poverty Traps, ed. S. Bowles, S. Durlauf and K. Hoff. Princeton, NJ: Princeton University Press, 2006.

[10] Bowles, S., Durlauf, S. and Hoff, K., eds. Poverty Traps. Princeton, NJ: Princeton University Press, 2006.

[11] Bowles, S. and Gintis, H. "The inheritance of inequality." Journal of Economic Perspectives 16, no. 3 (2002): 3-30.

[12] Carter, L. and Margo, R. "Feminization of teaching in the United States." In Gender and Education in the United States, ed. B. Bank. Westport, CT: Greenwood Press, 2007.

[13] Chiswick, R.. "The occupational attainment of American Jewry: 19902000." IZA Discussion Paper No. 1736. Bonn, Germany: Institute for the Study of Labour, 2005. 
[14] Collins, W. "When the tide turned: immigration and the delay of the Great Black migration." Journal of Economic History 57 (1997): 60732.

[15] Collins, W. "African-American economic mobility in the 1940s: a portrait from the Palmer Survey." Journal of Economic History 60 (2000): $756-81$.

[16] Collins, W. "Race, Roosevelt, and wartime production: fair employment in World War II labor markets." American Economic Review 91 (2001): 272-86.

[17] David, P. "Clio and the economics of QWERTY." American Economic Review Papers and Proceedings 75, no. 2 (1985): 332-7.

[18] David, P. "Why are institutions the 'carriers of history'?: Path dependence and the evolution of conventions, organizations, and institutions." Structural Change and Economic Dynamics 5 (1994): 205-20.

[19] Donohue, J. III, and Heckman, J. "Continuous versus episodic change: the impact of the civil rights policy on the economic status of blacks." Journal of Economic Literature 29 (1991): 1603-43.

[20] Durlauf, S. "Group, social influences and inequality: a membership theory perspective on poverty traps." In Poverty Traps, ed. S. Bowles, S. Durlauf and K. Hoff. Princeton: Princeton University Press, 2006.

[21] Eckstein, Z. and Zilcha, I. "The effects of compulsory schooling on growth, income distribution and welfare." Journal of Public Economics 54 (1994): 339-59.

[22] Fujita, M., Krugman, P. and Venables, A. The Spatial Economy: Cities, Regions, and International Trade. Cambridge, MA: MIT Press, 1999.

[23] Galor, O. and Zeira, J. "Income distribution and macroeconomics." Review of Economic Studies 60 (1993): 35-52.

[24] Goldin, C. "Monitoring costs and occupational segregation by sex: a historical analysis." Journal of Labor Economics 4 (1986): 1-27.

[25] Goldin, C. Understanding the Gender Wage Gap: An Economic History of American Women. Chicago: University of Chicago Press, 1990.

[26] Goldin, C. and Katz, L. "The 'virtues' of the past: education in the first hundred years of the new republic." Working Paper No. 9958. Cambridge, MA: NBER, 2003.

[27] Greif, A. "Reputation and coalitions in medieval trade: evidence on the Maghribi traders." Journal of Economic History 49 (1989): 857-82. 
[28] Krugman, P. "History and industry location: the case of the manufacturing belt." American Economic Review Papers and Proceedings 81, no. 2 (1991a): 80-3.

[29] Krugman, P. "Increasing returns and economic geography." Journal of Political Economy 99 (1991b): 483-99.

[30] Kuznets, S. "Economic structure and life of the Jews." In The Jews: Their History, Culture, and Religion, ed. Louis Finkelstein, Philadelphia: Jewish Publication Society of America, 1960.

[31] Liebowitz, S. and Margolis, S. "Path dependence, lock-in, and history." Journal of Law, Economics, \& Organization 11 (1995): 205-26.

[32] Long, J. and Ferrie, J. "A tale of two labor markets: intergenerational occupational mobility in Britain and the United States since 1850." Working Paper No. 11253. Cambridge, MA: NBER, 2005.

[33] Loury, G. "Intergenerational transfers and the distribution of earnings." Econometrica 49 (1981): 843-67.

[34] Loury, G. The Anatomy of Racial Inequality. Cambridge, MA: Harvard University Press, 2002.

[35] Margo, R. Race and Schooling in the South, 1880-1950: An Economic History. Chicago: University of Chicago Press, 1990.

[36] Mookherjee, D. and Ray, D. "Persistent inequality." Review of Economic Studies 70 (2003): 369-93.

[37] Mookherjee, D. and Ray, D. "Contractual structure and wealth accumulation." American Economic Review 92 (2002): 818-49.

[38] Perlmann, J. and Margo, R. Women's Work? American Schoolteachers, 1650-1920. Chicago: University of Chicago Press, 2001.

[39] Rotella, E. From Home to Office: U.S. Women at Work, 1870-1930. Ann Arbor, MI: UMI Research Press, 1981.

[40] Shelling, T. "Dynamic models of segregation." Journal of Mathematical Sociology 1 (1971): 143-86. 